\title{
Hominins without fellow travellers? First appearances and inferred dispersals of Afro- Eurasian large-mammals in the Plio-Pleistocene
}

\author{
H.J. O'Regan ${ }^{\mathrm{a}}$, A. Turner ${ }^{\mathrm{a}}$, L.C. Bishop ${ }^{\mathrm{a}}$, S. Elton ${ }^{\mathrm{b}}$, A. Lamb \\ ${ }^{a}$ Research Centre in Evolutionary Anthropology and Palaeoecology, School of Natural \\ Sciences and Psychology, Liverpool John Moores University, Liverpool, L3 3AF, UK \\ ${ }^{b}$ Functional Morphology and Evolution Unit, Hull York Medical School, University of Hull, \\ Cottingham Road, Hull, HU6 7RX, UK \\ ${ }^{c}$ NERC Isotope Geosciences Laboratory, British Geological Survey, Keyworth, Nottingham, \\ NG12 5GG, UK
}

\begin{abstract}
Discoveries of fossil Homo outside Africa predating 1.0 Ma have generated much discussion about hominin dispersal routes. However, tool-using bipeds were only one element of the inter-continental mammalian dispersals that occurred during the climatic changes of the Pliocene and Pleistocene. This paper will place hominin movements in the context of those of the wider mammalian fauna, which includes carnivores, bovids and non-human primates. The distribution of these different taxa suggests that species moved individually when the environmental conditions were right for them, rather than in multi-species waves of dispersal, and allows evaluation of the contextual evidence for the newly emerging 'Out of Asia' paradigm as well as the established 'Out of Africa' model.
\end{abstract}

\section{Introduction}

In previous papers (O’Regan et al., 2006, Turner and O’Regan, 2007 a,b) we have discussed the biogeography of Eurasian Plio-Pleistocene mammals with particular emphasis on movements out of Africa and the timescale and direction of early hominin dispersal events. Those studies concluded that movements across the Gibraltar Straits during the Pliocene and Pleistocene can be ruled out for terrestrial mammals, with the possible exception of the hippopotamus (see O'Regan, 2008). Although a late Pliocene dispersal across the opening Bab-el-Mandeb region of the southern Red Sea may have been possible, such a route appears an unlikely choice for a Pleistocene gateway. Such evidence for human and other mammal 
occupation of the Arabian Peninsula as does occur is beset by problems of chronological control but may be best explained by incursions southward from the Levant rather than by movement directly from the Horn of Africa.

Here we wish to change the emphasis from specific routes of movement and to look instead at the first appearance data for large-mammals in Afro-Eurasia in order to investigate overall patterns of dispersal between those continental areas. Various waves of PlioPleistocene Afro-Eurasian mammalian dispersal have previously been identified in the palaeontological literature, the best known of which are the dispersal of Proboscidea out of Africa 2.5-1.5 Ma (Tchernov and Shoshani, 1996), of bovids out of Africa 2.7-2.5 Ma (Vrba, 1995a) and the Elephant-Equus and Wolf events in Europe at 2.6-2.5 Ma and 1.7 Ma respectively (Azzaroli et al., 1988). Other dispersals of interest include the appearance of cold-tolerant faunas in Europe and of larger-bodied cervids and bovids in western parts of Eurasia during the Pleistocene (Azzaroli et al., 1988), and of course the pattern and timing of earliest hominin movements (Dennell, 2003; Roebroeks, 2001; Turner, 1992, 1999). Our results, in combination with those of several other recent studies, suggest that a number of these previous interpretations require reconsideration.

The information collated here was largely collected as part of a NERC-funded thematic programme which considered the Environmental Factors in the Chronology of Human Evolution and Dispersal (EFCHED), and thus we have concentrated on the later Pliocene and Pleistocene, from 3.0 Ma to 0.5 Ma. Since we shall examine the bearing that our results have on the questions that surround interpretations of early hominin dispersals, it will be useful to begin with a summary of the current picture of earliest hominin presence and the broad pattern of dispersals that may be inferred from it.

\section{Hominin dispersals}


An African origin some time during the later Pliocene/earliest Pleistocene is the most widely accepted model for the evolution of our own genus, Homo (Turner and O'Regan, 2007a,b). The earliest known hominin material outside Africa is from Dmanisi in Georgia ( 1.7 Ma). The sample is now reasonably extensive (Gabunia et al., 2002), and in the light of relatively primitive morphology it has been assigned to either a very primitive form of $H$. erectus (Rightmire et al., 2006) or a new species H. georgicus based on mandible D 2600 (de Lumley et al., 2006). The most recent review of this material has placed $H$. georgicus closer to the Homo habilis - Homo rudolfensis lineage than to H. ergaster/H. erectus (de Lumley et al., 2006). This would perhaps indicate a first Late Pliocene/ Early Pleistocene dispersal of most primitive Homo to Dmanisi. A date of 1.8 Ma has been claimed for Homo erectus in Java (Swisher et al., 1994), but the earliest evidence is now considered to be from the top of the Sangiran Formation at ca 1.6 Ma (Bettis et al., 2009). Claims have been made for Homo sp. at 1.7 Ma in Yuanmou in southern China (Zhu et al., 2008), although Dennell (2009) has expressed strong reservations about the identity of the material. The next earliest hominin fossils, isolated teeth from 'Ubeidiya in Israel, dated to $1.5 \mathrm{Ma}$ (Belmaker et al., 2002), have been tentatively attributed to Homo erectus or H. ergaster. The Early Pleistocene hominin record has recently been extended in Europe with the publication of a hominin mandible from the Sima del Elefante at Atapuerca, dated to between 1.2-1.1 Ma (Carbonell et al., 2008).

Earliest archaeological remains have also been recovered from Dmanisi and are regarded as Oldowan (or Pre-Oldowan) by their excavators (de Lumley et al., 2005). The Oldowan is first recorded in Africa at around 2.6 Ma at Gona in Ethiopia (Semaw et al., 2005). Other Early Pleistocene sites outside Africa with Oldowan (Mode 1) technology are found in Spain (Barranco-Leon 5 and Fuente-Nueva 3 and lowest levels of Atapuerca (MartínezNavarro et al., 1997; Gibert et al., 1998; Oms et al., 2000; Carbonell et al., 2008)), and are claimed at Pirro Nord in Italy, 1.6-1.3 Ma (Arzarello et al., 2007), the Pabbi Hills in Pakistan 
$\sim 1.9 \mathrm{Ma}$ (Dennell, 2004), Yuanmou in southern China $1.7 \mathrm{Ma}$ (Zhu et al., 2008) and Majuangou in north eastern China dated to 1.66 Ma (Zhu et al., 2004). In contrast the lithic technology at 'Ubeidiya is Acheulean, a form that first appears $\sim 1.7$ Ma at Konso Gardula in Ethiopia (Asfaw et al., 1992). Its presence at 'Ubeidiya suggests at least one hominin dispersal out of Africa occurred between 1.7 Ma and 1.5 Ma.

There are many more records of hominin fossils and archaeological sites in the Eurasian Middle Pleistocene. The earliest examples from around the Early - Middle Pleistocene transition include Gesher Benot Ya'aqov (Geraads and Tchernov, 1983), Atapuerca (Falguères et al., 1999), and Ceprano (Ascenzi et al., 2000). Archaeological material has also been reported from Flores in Indonesia at $\sim 0.8 \mathrm{Ma}$ (Morwood et al., 1998).

\section{Methods}

Our aim is to look for large scale patterns of dispersal. One of the problems when conducting such an analysis is the potential for variation in taxonomy over such a large area, and we have therefore examined faunal movements at the sub-family and tribal levels before going on to consider things in more detail at the generic or specific level. As we are interested in the dispersal of hominins and other medium to large terrestrial mammals, records of Chiroptera, Sirenia, Cetacea, Phocidae (earless seals) and Otaridae (walruses and sealions) are not included. Members of four other terrestrial orders are also excluded - the Lagomorpha, Rodentia, Hyracoidea and Lipotyphla (a suborder of insectivores containing amongst others hedgehogs, shrews and moles) as these contain mainly small-bodied taxa with sparse or uncertain fossil records. The remaining families are subdivided at sub-familial and tribal levels where appropriate, as shown in the supplementary data. The data used to create this table were downloaded from the Palaeobiology Database (PBD) (www.paleodb.org), a large part of the relevant section of which had been compiled by us (during the NERC funded 
Palaeoinformatic context for the earliest hominin dispersals project, PACED). A total of 1335 Pliocene and Pleistocene Afro-Eurasian sites or localities with larger mammal faunas were thus examined. A few key sites were not represented in the database, so the faunal lists for these were taken from the literature (see supplementary information). In order to begin the examination of faunal differences over time in each continent the sites were binned into periods spanning 500,000 years. While other bin sizes could have been chosen it was felt that this would give us a reasonable starting point from which to consider distributions of taxa in time and space in more detail. We chose to stay with the conventional continental divisions; other divisions might have been selected, perhaps viewing Europe as a western peninsula of the Europan landmass, but again some starting point was necessary and that is how the material is generally presented in the literature. The dates were assigned using data provided in the PBD or in published records, although some sites were either too early (dated prior to 3.0 Ma) or too late (post dating $0.5 \mathrm{Ma}$ ), and these were removed from the dataset while others could not be assigned a date to within 1 million years and were subsequently excluded. Dates must, of course, be treated with care; resolution is variable and many are no more than estimates, so that once again the groupings that follow from assigning dates are taken as a starting point for more detailed consideration in the text.

This left a total of 904 sites or localities which have been included in the analysis. It must be noted that there is an unequal geographic spread of sites within the PBD. African sites are well represented by the ETE (Evolution of Terrestrial Ecosystems) records and much of the European and Central Asian records are covered by the PACED dataset. However, far fewer Eastern Asian sites are included, although fortunately several recent reviews of the Asian faunas have been published (Chauhan, 2008; Deng et al., 2008; Nanda, 2002, 2008; Tong, 2006, 2007; Zhu et al., 2008) and these have been incorporated where appropriate. The 
breakdown of localities per continent is as follows: Asia $=63$, Africa $=526$, Europe $=306$, and the Levant $=9$. Further details can be found in the supplementary information .

\section{Results}

From the large-scale analysis of sites on a continental basis some broad patterns can be seen (see supplementary information table 1). The Cervidae are present in Europe and Asia, and absent from Africa, while the majority of Bovid tribes are only found in Africa. However, some finer scale detail can be identified, for example the appearance of the reindeer, a member of the Odocoilieni, in Europe and Asia after 1.0 Ma. Some bovid tribes are ubiquitous, found in all regions and all time periods, such as the Bovini and Antilopini, while others such as the Peleini have a restricted range in both time and space. Certain other groups, including the Equidae (which includes both Equus and Hipparion), the Elephantinae and the Rhinoceroti, are also found in all time periods and regions. The arrival of the Pantherinae and Hominini can be seen in Europe and Asia. Thus the broad-scale differences between continents in terms of their faunal distributions can clearly be identified, even at a high (family, subfamily or tribal) taxonomic level.

However, the details of these movements are seen at the generic or specific level, and these have been identified from the literature. Table 1 summarises all identified first appearances of taxa of African origin outside Africa. Europe, the Levant and Asia have been listed separately, although Asia includes central Asia (e.g. Georgia, Tadjikistan) as well as Eastern Asia (China, India, Indonesia). In the text we treat the patterns of movement in terms of broad continental headings and directions, since we feel this conveys the most information to the reader. 


\subsection{Out of Africa}

For the mammalian fauna in general, relatively few taxa migrate from Africa between $3.0-0.5 \mathrm{Ma}$. In total, members of 13 genera dispersed from Africa during this time - Homo, Theropithecus, Panthera, Megantereon (as M. whitei), Crocuta, Pachycrocuta, Hippopotamus, Palaeoloxodon, Hippotragus, Oryx, Damalops, Pelorovis, Kolpochoerus. A further five genera, Parahyaena, Giraffa, Vishnukobus, Sivacobus and Potamochoerus may also have dispersed, as discussed below. Nine of these African genera are found in Europe, nine in SW Asia, six in central Asia and 10 in eastern Asia (China, India-Pakistan Siwaliks deposits). The first appearances of these taxa in Eurasia are shown in Table 1.

As summarised in the previous section, the genus Homo is first recorded at Dmanisi in Georgia, followed by Java and Yuanmou although these may represent a different species, and then at 'Ubeidiya but with a different tool technology. No fossils are found in Europe until 1.2-1.1 Ma, but archaeological sites may predate this occurrence (indicated by ' $a$ ' in Table 1). The only other primate to have dispersed beyond the Arabian Peninsula in the PlioPleistocene was Theropithecus cf. T. oswaldi, remains of which have been found in India and Spain, with more doubtful occurrences in Italy and Israel (see Hughes et al., 2008, for discussion).

The earliest find of the genus Panthera outside Africa may be P. palaeosinesis from China, although the age is not clear. Christiansen (2008) suggests that the holotype may only be of Early or Middle Pleistocene age, but claims so-far unpublished material may be from Late Pliocene horizons. The Yuanmou deposits in China contain records of Panthera tigris at $\sim 1.7 \mathrm{Ma}$ (Zhu et al., 2008) and there is another Eurasian member of the genus, the jaguarsized P. gombaszoegensis, which is first recorded in Europe at the very end of the Pliocene (Spassov, 1998; O’Regan and Turner, 2004). Whether P. gombaszoegensis had an African or Asian origin, or was a European endemic species, is still unknown (Sardella and Palombo, 
2007). The appearance of the modern lion (P. leo) and leopard ( $P$. pardus) in Europe is much later; leopard is first known at Le Vallonet in France, which dates close to the Jaramillo Event, while lion is currently first seen at Pakefield in England (Parfitt et al., 2005; Turner, 2009, Lewis et al., in press). Based on the different first appearance dates of these species, it is conceivable that members of the genus Panthera dispersed from Africa several times during the Pleistocene. The sabretoothed cat genus Megantereon has recently been subject to a detailed study of cranial and dental morphometrics (Palmqvist et al., 2007), which concluded that a more primitive Eurasian species, $M$. cultridens, existed in Eurasia until the end of the Pliocene and was then replaced by the more derived African species, Megantereon whitei, first seen at Dmanisi.

The spotted hyaena genus Crocuta is first found in Asia in the upper part of the Nagrota formation (beginning at $2.5 \mathrm{Ma}$ ) in India, which is equivalent to the Pinjor formation of the Siwaliks (Nanda, 2002, Basu, 2004). The extant species Crocuta crocuta is certainly recorded by Turner (2004) at localities 68 and 73 in the Siwaliks of Pakistan, the latter dated between 1.4-1.2 Ma (Dennell et al., 2006). However the earliest known occurrence of Crocuta crocuta in Europe is at Atapuerca in Spain below the Brunhes-Matuyama boundary (Garcia and Arsuaga, 2001). The large, short-faced hyaena Pachycrocuta brevirostris is first recorded in Europe in earliest Pleistocene deposits (Turner and Antón, 1996), but it is certainly present in Asia (Turner, 2004; Dennell et al., 2008) and Africa (Turner, 1990) at around that time. The earliest date currently cited for Africa is for material from the South Turkwel site in northern Kenya (Werdelin and Lewis, 2000) in deposits dated between 3.58 and 3.2 Ma, and although the material is scanty and less than ideal it would seem that an origin for the genus in Africa is indicated.

The extant African brown hyaena, Parahyaena brunnea, has recently been identified in Spain at the site of Fonelas in deposits dated to $1.8 \mathrm{Ma}$ (Viseras et al., 2006). This is the first 
record of this species in Europe, but it may be more plausibly explained as a late appearance of the Eurasian Pliocene species Pliocrocuta perrieri. This latter species disappears from European deposits at the end of the Pliocene and then reappears in the Middle Pleistocene, possibly from a refugium in Asia but also possibly from one in Portugal (Turner et al., 2008). The species are very similar morphologically, if not identical (Turner, 1990), although recent claims for an early member of the genus Parahyaena in Africa from around 4.0 Ma at Kanapoi (Werdelin and Lewis, 2005) could suggest an ultimate origin in Africa but before the period of concern to us here.

The other extant hyaenid that might concern us is the striped hyaena, Hyaena hyaena, which is found across northern Africa, the Arabian Peninsula, southern Turkey and across into India (Rieger, 1981). However, previous claims for its appearance (in the form of Hyaena prisca) in European Pliocene and Pleistocene deposits can now be discounted (Turner et al., 2008), and it essentially has no fossil record outside Africa (Werdelin and Solounias, 1991) so that we can offer no assessment of its dispersal pattern.

Hippos have very complex pattern of dispersal, with at least 3 different species in the Levant (Table 1) one of which appears to have been an endemic (H. behemoth). The first appearance of Hippopotamus in Europe is at Venta Micena in the Early Pleistocene (Martínez-Navarro and Palmqvist, 1995), and it is found as far East as Akhalkalaki in Georgia (Vekua, 1986; Hemmer et al., 2001) - hence its inclusion in the Asian section of Table 1. Hippopotamus is not found elsewhere in Asia, with the possible exception of India where both Hexaprotodon and Hippopotamus are recorded (but may in some cases be synonymous (Chauhan, 2008)). There are no reliable records of Hippopotamus from China (Tong, 2007).

Palaeoloxodon antiquus, the straight tusked elephant, is first found in Asia at $1.36 \mathrm{Ma}$ and in Europe and the Levant after 1.0 Ma (Table 1). However, in Asia it was confined to the Palaearctic regions (Tong, 2007), and all Palaeoloxodon records in peninsular India now 
appear to be Elephas (Chauhan, 2008), the genus to which the extant Indian elephant belongs. There is also a tentative identification of cf. Elephas recki at An Nafud in Saudi Arabia, which is dated to the Early Pleistocene (Thomas et al. 1998).

The indisputably African suid Kolpochoerus olduvaiensis is found at 'Ubeidiya in Israel (Geraads et al., 1986) dated to $\sim 1.5 \mathrm{Ma}$ (Belmaker et al., 2002). The second record of Kolpochoerus from Israel appears to be of an endemic species, K. evronensis (Haas, 1970) from the site of Evron Quarry, and the genus therefore seems to have dispersed from Africa but to have got no further than the Levant. However, Martinez-Navarro (2004) has mentioned that it may also occur in India. The bushpig genus Potamochoerus is reported in both the Siwaliks and Peninsula India by Nanda (2008), but Chauhan (2008) examines some of the same faunal localities and does not mention it. Relatively few taxa of African origin appear in India south of the Siwaliks complex, but this may in part be due to a lack of discovery or exploration of similarly aged deposits (Chauhan, 2008). A new species of Potamochoerus has also been identified at Fonelas in Spain by around 1.8 Ma (Viseras et al., 2006), which may indicate a dispersal from Africa or possibly Asia.

Six bovid taxa of African origin have been identified in SW Asia, central Asia and the Siwaliks deposits of southern Asia. The earliest record is of a member of the genus Hippotragus - H. brevicornis - in the Tatrot Formation of the Siwaliks in India and Pakistan (Vrba and Gatesy, 1994). The latest part of the Tatrot Formation is dated to $2.58 \mathrm{Ma}$ (Nanda, 2002), indicating that the appearance of Hippotragus in this deposit must be the result of a middle Pliocene dispersal from Africa, prior to $\sim 2.6 \mathrm{Ma}$ at the latest. The overlying Pinjor Formation of the Siwaliks contains the best record of bovids with African origins, since Oryx sivalensis, Hippotragus bohlini, Damalops palaeindicus, Vishnukobus patulicornis and Sivacobus palaeindicus have all been recorded from these deposits (Vrba \& Gatesy, 1994, Vrba, 1995a). Vrba (1995a: 397) suggested that this appearance might be the result of a 
second wave of migration which 'involved five African emigrants very close to or soon after 2.7 Ma'. However, detailed analysis of the dating, the Siwaliks sites and the palaeoecology of the animals themselves indicates that this may not be such a clear signal. Estimates of the duration of the Pinjor Formation vary greatly throughout its geographic range, and it has generally been treated as an undifferentiated unit although Dennell et al. (2006) have attempted a subdivision of the earlier portion based on material from the Pabbi Hills of Pakistan. The upper level in contact with the overlying Lower Boulder Conglomerate has been variously estimated to be between $1.72-0.6$ Ma depending on whereabouts in India and Pakistan the deposits are found (Nanda, 2002, 2008). As they have been found in the Pinjor Formation, these 'African' bovid specimens cannot be earlier than $2.58 \mathrm{Ma}$ (the latest date of the Tatrot Formation (Nanda, 2002), but they could potentially be as young as the Middle Pleistocene. This is acknowledged by Vrba (1995a) and Vrba and Gatesy (1994) in the tabulated data, but is not made explicit in the text.

As noted above, Hippotragus brevicornis has previously been found in the Siwaliks, perhaps indicating that the appearance of a new species of Hippotragus (H. bohlini) in the Pinjor formation was a result of endemism and not necessarily evidence for a new dispersal out of Africa. Both $H$. brevicornis and H. bohlini were originally assigned to the genus Sivatragus by Pilgrim (1933), but were referred to Hippotragus by Vrba and Gatesy (1994) and Vrba (1995a). However, a cladistic analysis conducted by Vrba and Gatesy (1994) indicates that $H$. bohlini shares some features in common with later African forms, and not with the earlier $H$. brevicornis, and they suggested that $H$. brevicornis might represent a new genus and a sister taxon to Hippotragus sensu stricto. If $H$. bohlini were more closely related to the African hippotragines than to H. brevicornis that preceded it in the Siwaliks deposits then this would indicate a second, undated, out-of-Africa movement for members of this genus. 
The genus Oryx is first recorded outside Africa as Oryx sp. indet. at the Pliocene site of Kvabebi in Georgia (Gabunia, 1974) and then later as Oryx sivalensis in the Pinjor Formation (Vrba, 1995a). Since the genus Oryx was already present in Eurasia it is not certain that its presence in the Siwaliks can be taken as evidence of a new dispersal out of Africa, and it may just represent movement within Asia. Oryx is a lineage with adaptations to arid environments, indicating that the earlier representatives could have survived in more open conditions (Estes, 1991; Vrba 1995a). By the late Early Pleistocene a desert adapted form is recorded from An Nafud in Saudi Arabia (Thomas et al. 1998). In contrast, Sivacobus palaeindicus from the lechwe lineage (Vrba, 1995a), and Vishnukobus patulicornis from the reduncine kob lineage (Vrba, 1995a) are both members of the Reduncini, a tribe which includes the extant lechwe (Kobus leche) and waterbuck (Kobus ellipsiprymnus), animals with a strong preference for flood plains and other areas close to water (Estes, 1991). The genus Damalops is recorded in both the Pinjor Formation (Vrba, 1995a) and at the site of Kuruksay-Navrukho in Tajikistan dated to the Late Pliocene, or MN 17 (Sotnikova et al., 1997). Damalops is an extinct African alcelaphine, so there are no data on the environmental preference of the genus. However, the Alcelaphini as a whole prefer an open landscape with short grass and they can also tolerate tree cover, but are not desert adapted (Estes, 1991). The sixth African bovid from the Pinjor formation is simply recorded as Alcelaphini indet., so the environmental information given for Damalops is also of relevance.

Indeterminate alcelaphines are also found in the palaeontological record of the SW Asia from the early Pleistocene onwards at An Nafud localities 1 and 2 and Evron Quarry (Thomas et al., 1998; Tchernov et al., 1994). Hippotragini indet. cf Hippotragus sp. is recorded at 'Ubeidiya by Gaudzinski (2004), but not by Belmaker (2006).

The extinct African buffalo species Pelorovis oldowayensis is recorded in the Levant, at 'Ubeidiya (Tchernov et al., 1994), and as P. cf. P. oldowayensis in Saudi Arabia at An Nafud 
localities 1 and 3 (Thomas et al., 1998). Pelorovis cf. P. bubaloides (a north African species) was recorded at Gesher Benot Ya'acov by Martinez-Navarro (2004), although Tchernov et al. (1994) listed all large bovid remains from Gesher as Bos sp. As discussed in the following section, Martinez-Navarro et al. (2007) have recently suggested that all these remains should be referred to Bos, although there is not enough material from Gesher to permit a formal identification of the species.

The genus Giraffa is only found in Africa today, but probably had an Asian origin and the relationship between the African and Eurasian species have not yet been resolved (Mitchell and Skinner, 2003). However, members of the genus Giraffa are found in the Levant at Bethlehem and 'Ubeidiya, and the Middle Pleistocene giraffe at Latamne in Syria is suggested to be conspecific with the extant Giraffa camelopardalis (Guérin et al., 1993). If this is the case, then this may suggest a dispersal from Africa in the Middle Pleistocene, as $G$. camelopardalis is known in Africa from 1.0 Ma onwards (Mitchell and Skinner, 2003). However, there is a possibility that it could be a Pliocene relict, as suggested by Belmaker (2006).

Of the nine African genera found in SW Asia there are only three that may not be present elsewhere in Eurasia - Giraffa, Kolpochoerus and Pelorovis - although, as mentioned above, Martínez-Navarro (2004) suggests that Kolpochoerus may have dispersed into India, and the records of Giraffa may not indicate a dispersal. In addition to these genera some indeterminate alcelaphines have also been recorded in SW Asian sites and Hippopotamus gorgops is only found in the Levant. The wide range of animals dispersing from Africa suggests that there was no taxonomic or ecological bias on animals entering SW Asia, and that only a limited number of taxa became isolated and speciated there (e.g. Kolpochoerus and Hippopotamus). Belmaker (2006) provides a useful discussion of the environmental tolerances of each taxon found at 'Ubeidiya and the potential limitations to their dispersal. 
There has often been an emphasis on the Levant as a key to understanding the dispersal of faunas in the Plio-Pleistocene (Tchernov, 1992; O'Regan et al., 2005, Turner, 1999), since this is considered the most likely dispersal route for macromammalian taxa (O'Regan et al., 2006; Turner and O'Regan 2007a, b). However, this approach may limit interpretations as there are only seven sites in the Levant for the time period in question, or a total of nine if the three An Nafud localities in Saudi Arabia included (Thomas et al., 1998). As we are concerned with placing the hominin fossil record in its faunal context we are interested in those animals that dispersed beyond the Arabian peninsula, as Homo did, so the paucity of sites in the Levant does not prevent the analysis of patterns of movement. It does however constrain our understanding of when animals may have moved, as only one site is known in the late Pliocene (Bethlehem), two in the Lower Pleistocene ('Ubeidiya, An Nafud) and four from the early-Middle Pleistocene (Gesher Benot Ya'acov, Latamne, Evron Quarry and the lowest levels of Tabun) - hence the clustering of first appearances around 2.5 Ma, 1.5 Ma and 1.0-0.8 Ma in Table 1 (and see supplementary information). In the case of taxa such as Palaeoloxodon it is unlikely that they could have dispersed into Eurasia without passing through the Levant, so the later Levantine appearance shown here in Table 1 is likely to be an artefact of the lack of sites. Whether the same argument can be made about Homo seemingly being found earlier at Dmanisi and then later at Ubeidiya is doubtful, based on the morphology of the specimens and their associated artefacts at each locality.

In summary, the latest identified dispersal from Africa is that of Palaeoloxodon at roughly $1.3 \mathrm{Ma}$, although it is possible that lions, leopards, Giraffa and Bos moved later (see Martínez-Navarro, 2004, Martínez-Navarro et al., 2007 and below, next section). Only seven genera of African origin are found in both Europe and Asia - Pachycrocuta, Crocuta, Panthera, Palaeoloxodon, Homo, Theropithecus and Megantereon (the latter as M. whitei replacing the earlier M. cultridens) with the possible addition of Potamochoerus and 
Hippopotamus, although both require further investigation. Several 'African' genera that are found in Europe after 1.2 Ma, such as Panthera, Crocuta, Palaeoloxodon and Homo, are all found in Asia prior to their first appearance in Europe.

\subsection{Into Africa}

In comparison with the 13 genera dispersing from Africa between 3.0-0.5 Ma, only four genera definitely entered the continent over the same period: Equus, Nyctereutes, Lycaon and Antilope, although Mammuthus meridionalis is reported at Ain Hanech in Algeria (Sahnouni and de Heinzelin, 1998).

However, numerous members of the tribes Ovibovini (Nitidarcus, Damalavus, plus two indeterminate Ovibovines), Caprini (Makapania, Bouria, Parantidorcas, plus six indeterminate Caprines) and Alcelaphini (Numidocapra) are recognised within Africa. The

difficulty here is to decide whether these bovids represent individual incursions into Africa, as suggested by Vrba (1995a) in the case of the Caprini, or evolution within Africa because no fossils outside that continent have been assigned to the genus, as in the case of Numidocapra (Vrba, 1995a). If each is regarded as a separate incursion into Africa, then there were a total of 17 movements, but if only the first appearance of each tribe is counted, and the rest assumed to be the result of in situ speciation, only six movements occurred.

Because of the uncertainty over these findings, these taxa are not included in Table 1, but their appearances and dates are summarised here as a basis for future work in this area. The data on bovid appearances are mainly from Vrba (1995a). The Eurasian genus Antilope has been recorded from several sites in Africa, particularly two specimens of Antilope aff. A. subtorta at Shungura C5 (2.74-2.5 Ma) (Vrba, 1995a; Bobe and Eck, 2001) and Omo L45 (2.8-2.5 Ma). In addition to Parantidorcas latifrons from Ain Boucherit in Algeria dating between 2.7-2.5 Ma, Vrba (1995a) recorded the appearance of 5 different types of "?Caprini 
indet. A-D", and "?Caprini indet sp". All of these records are from East Africa, with "?Caprini indet A" being found twice at Lokalalei in West Turkana between 2.52-2.35 Ma, and again at Nariokotome in Kenya between 1.39-0.8 Ma. The next earliest in Vrba's scheme is "Caprini indet. C", recorded from Upper Lomekwi below 2.5 Ma and at Nariokotome after 1.39 Ma. "?Caprini indet. sp." is in the Shungura formation, dated between 2.5-2.33 Ma. Both "? Caprini indet. B" and "D" are found in the Natoo Formation, dating between 1.65-1.33 Ma. Vrba (1995a) regards each appearance of these caprines as evidence of a separate incursion into Africa, as the Caprines as a group originated in Eurasia. However, it is possible that some of them could have been present in Africa in low numbers and may not represent a separate later incursion, since "Caprini indet A" and "C" are known from both the late Pliocene and the late Early Pleistocene. Martinez-Navarro et al. (2004) record Caprini indet from Bouri, and Asfaw et al. (2002) have a new genus and species of caprine, Bouria anngettyae, recorded from Daka (1.0-0.8 Ma). Clearly, more work needs to be done on these bovids, and at present many questions about dispersals and distributions remain unanswered.

The only find of true Bos in sub-Saharan Africa is a record of Bos cf. B. primigenius dating to 0.8-0.6 Ma at Asbole in Ethiopia (Alemseged and Geraads, 2000; Geraads et al., 2004), indicating an early Middle Pleistocene immigration for this genus. However, a revision of the genus Bos (Martínez-Navarro et al., 2007) suggests that Pelorovis and Bos may be congeneric, forming three chronospecies, Bos turkanensis, B. oldowayensis and B. primigenius, with the latter dispersing from, rather than into, Africa at around 0.6 Ma. This study is based on a geometric morphometric analysis of a limited number of specimens, and further work will be required to determine if this scenario is correct. Therefore we have retained Pelorovis for the African and Levantine material as it highlights the arrival of bovines with a distinctive morphology, only otherwise known in Africa, in the Arabian Peninsula. However, we acknowledge that if Martínez-Navarro et al. (2007) are correct then 
Bos would form the latest dispersal from Africa into Europe in the time period considered here, and did so at the very late date of $\sim 0.6 \mathrm{Ma}$.

Only three non-bovid taxa dispersed into Africa between 3.0-0.5 Ma. Two were carnivores - the raccoon dog genus Nyctereutes is found in both north and South Africa from 2.5 Ma onwards (Geraads, 1997; Ficcarelli et al., 1984), whilst the African hunting dog genus, Lycaon, is first found in north and east Africa at $\sim 1.8 \mathrm{Ma}$ (Martínez-Navarro and Rook, 2003). Both were widespread in Eurasia before entering Africa (if Xenocyon and Lycaon are synonymous). The third genus was Equus, the monodactyl horse, which is found throughout Africa from 2.3 Ma onwards (Bobe and Behrensmeyer, 2004). The timings of these dispersals indicates that, with the exception of two possible caprine movements and the now doubtful first appearance of Bos in East Africa (Geraads et al., 2004), all arrivals of Eurasian fauna into Africa predated 1.3 Ma.

\subsection{Out of Asia}

Asia is a vast and diverse area, and much further work is required to fully integrate the Asian record with that from Europe and Africa. There is an absence of deposits in the Indian region south of the Siwaliks for this period, so it is difficult to determine what was happening here (Chauhan, 2008). The fauna of peninsular India appears to have followed a different evolutionary trajectory from that of other areas (Chauhan, 2008), and it is possible that it served as a dead end for dispersals. Northern China shares many species with Europe, but there was clearly a different fauna in oriental China, although there is evidence of mixture with cooler faunas from the north (Tong, 2006, 2007).

At least four of the 'African' taxa listed in Table 1, Homo, Palaeoloxodon, Panthera and Crocuta, are found earlier in Asia than they are in Europe. One explanation, suggested by recent GIS modeling of later Homo sapiens dispersal in the Arabian and Indian peninsulas 
(Field et al. 2007), is that routes can be found up the Levantine coast, or along the coast of India. This may indicate that it was easier for some species to get into Asia than directly into Europe. Furthermore, dispersal models of Theropithecus (Hughes et al., 2008) found a similar pattern, and both seem to fall in line with the suggestion that an area of savannah grasslands ('Savannastan’), stretching from Africa into southwestern Asia, united areas that are traditionally placed in separate biogeographic compartments (Dennell 2003; Dennell and Roebroeks 2005).

Recent work on Pleistocene hominin dental morphology suggests complexity of movement within Eurasia during the Middle Pleistocene rather than a discontinuous series of African incursions (Martinón-Torres et al., 2007), and this picture is supported by the results of a recent computer simulation study by Hughes et al. (2007) on hominin dispersal patterns in relation to climatic changes. It may be significant for ideas about a southern route to Asia that the animals shared with peninsular India are generally omnivores or carnivores. These animals are able to move along beaches taking what they can get, while bovids, equids and proboscideans may have had more difficulty surviving en route. The impetus to continued dispersal that might come from movement close to shorelines in otherwise harsh environments was stressed by Turner and O’Regan (2007b).

In contrast to the paucity of African taxa, the source of many of the bovids and of course cervids that dispersed into Europe was Asia, at both at Pliocene-Pleistocene boundary $\sim 1.9$ Ma (Spassov, 1998) and later at around the Early-Middle Pleistocene boundary (Azzaroli et al., 1988, Martínez-Navarro and Palombo, 2004). Numerous other species appear to have been widespread in both Europe and Asia, including the woolly rhino genus Coelodonta, the dhole Cuon alpinus and Trogontherium cuvieri, a large extinct beaver (Tong, 2006). It appears that Asia may have provided a reservoir for taxa such as the cheetah, Acinonyx, or Pliocrocuta perrieri, or a staging post for African taxa such as Homo, Panthera and Crocuta, 
as well as being the source of many of the cold-tolerant animals found in Europe in the Middle Pleistocene.

The Proboscidea have had a complicated history, since the genus Mammuthus originated in Africa but much of its later speciation and development appears to have occurred in Siberia and northern China in the late Pliocene and earliest Pleistocene (Lister et al., 2005). Thus they dispersed from Asia to Europe, SW Asia and perhaps north Africa from these areas (Table 1). A similar pattern is seen in the proboscidean genus Stegodon, which became extinct in Africa during the mid-Pliocene (Kalb, 1995), but dispersed into Asia in the Pliocene where it is found in the Tatrot formation of the Siwaliks (Nanda, 2008) and persisted until the late Pleistocene (Van den Bergh et al., 2008). In the Pleistocene it is found in the Siwaliks, peninsular India, China and Indonesia (Nanda, 2008; Chauhan, 2008; Tong, 2006; van den Bergh et al., 2001), but also reappears in SW Asia in the late early Pleistocene, having been found at Gesher Benot Ya'acov , Evron Quarry and Latamne (see O’Regan et al., 2005 and references therein), but does not return to Africa or enter Europe at this time.

\section{Discussion}

\subsection{Previously identified dispersal events}

Our investigations call into question the idea of a bovid dispersal out of Africa at 2.7-2.5 Ma based on the six 'African' bovid taxa identified in the Siwaliks deposits by Vrba (1995a). The oryx is previously known from sites elsewhere in central Asia prior to its first find in the Pinjor Formation, and its dispersal from Africa may therefore have occurred much earlier in the Pliocene. The first find of a hippotragine also predates the Pinjor Formation, although the later species Hippotragus bohlini may not be a descendent of the earlier animal H. brevicornis, and may therefore represent a second dispersal of this genus from Africa in the Pliocene. Damalops is a good contender for a genuine movement at $\sim 2.5 \mathrm{Ma}$ as it is found in two 
separate areas, Tajikistan and Pakistan, at roughly the same time (although the dating problems of the Pinjor Formation must be taken into account). Both Sivacobus and Vishnukobus are from known African tribes but are new genera, suggesting that they had time to evolve after they migrated but before they appeared in the fossil record. However, this taxonomic difference may not have represented that great a difference for the animals themselves, and it appears that bovids may speciate relatively quickly (it has been estimated that the main tribes appeared within the space of a few hundred thousand years in the Late Miocene or earliest Pliocene (Vrba, 1995b)), perhaps indicating that the new genera in the Siwaliks would not have required a very long period of isolation to become differentiated. It is therefore unlikely that the presence of endemic genera in the Siwaliks can be taken as an indication of a dispersal much more than a few hundred thousand years before they are found in the deposits, and unfortunately the chronology of the deposits is unclear. Work is being undertaken to recover new specimens with accurate recording of position within the formations, but no new 'African' bovid material has yet been found (Nanda, 2002). Overall then, of the six Siwalik bovids found, it appears that only Damalops palaeindicus can be regarded as a genuine late Pliocene immigrant, although Hippotragus bohlini may also be a possibility. The other species lack independent corroboration from other sites, and are found in a formation that certainly spans one million years and possibly two in some areas. In addition, the taxa have a variety of environmental tolerances, meaning that it is unlikely that they would all have migrated together - the arid-adapted oryx with the wetland-preferring lechwe for example - but rather the evidence seems to point to them moving alone when the environment was right for each individual species, and not as a 'wave' of dispersal out of Africa at 2.7 Ma.

Mammuthus dispersal into Europe was originally thought to coincide with the arrival of the horse genus Equus in Eurasia at $2.5 \mathrm{Ma}$ (Lindsay et al., 1980), later referred to as the 
elephant-Equus event by Azzaroli et al. (1988). However, the earliest mammoths and monodactyl horses have now both been found in Romania. Equus (= Pleshippus) is recorded at 3.9 $\mathrm{Ma}$ in the Oltet Valley (Radulesco and Samson, 1990, 2001), and Mammuthus rumanus, the most primitive Eurasian mammoth, is present at Tuluceşti and Cernăteşti in the Dacic Basin in deposits referred to mammalian biozone MN16a and correlated with the Gauss subchron, 3.5-3.0 Ma (Radulescu and Samson, 1990, 2001, Lister et al. 2005). This latter species is also found in the Yushe Basin in Northern China (Lister et al., 2005; Wei et al., 2006) indicating that the earliest mammoths were present in both Europe and Asia prior to 3 million years ago. This may represent a simultaneous dispersal of Mammuthus rumanus into both continents at the same time from an origin point in Africa (Lister et al., 2005). Tchernov and Shoshani (1996) suggested a wave of proboscidean dispersal out of Africa at 2.5-1.5 Ma, but from the information presented above it appears that the majority of proboscidean dispersals out of Africa occurred prior to $3 \mathrm{Ma}$, with the exception of Palaeoloxodon, which dispersed in the Early Pleistocene.

The 'wolf event' of Azzaroli et al. (1988) involving the first appearance of Canis is now thought to have occurred in the Pliocene rather than the earliest Pleistocene, and involved at least 4 different taxa, including the giant short-faced hyaena, Pachycrocuta brevirostris (Sardella and Palombo, 2007). The earliest known Canis, even if not demonstrably a 'wolf', is currently the material from Vialette in the Massif Central of France, dated to $3.14 \mathrm{Ma}$ (Lacombat et al., 2008). Members of the African hunting dog genus Lycaon may be the only instance of simultaneous dispersal into Africa and Europe from Asia. The earliest find of the genus is in China at 2.4 Ma, followed by 1.9 Ma in Europe and 1.8 Ma in north Africa (Martínez-Navarro and Rook, 2003). However, acceptance of this scenario is dependent on assuming that the earliest specimens of a very rare taxon have been found, and that Xenocyon and Lycaon are congeneric. 
The arrival of Equus in Europe was dated to 2.6 Ma and at 2.3 Ma in Africa (Lindsay et al. 1980). Despite intensive fieldwork in Africa no earlier Equus fossils have yet been found, but the earliest monodactyl horses in Europe now predate the dispersal into Africa by some 1.6 Ma (Radulesco and Samson, 1990, 2001).

It appears from the data we present in this paper that several of the well known faunal events in the later Pliocene and Pleistocene have been undermined. It may therefore be counterproductive to talk of the first appearance datum (FAD) of an animal or even groups of animals as an 'event', as these are constantly changing as new material is discovered and described.

\subsection{Repeated dispersals}

As discussed above, the record of caprine movements into Africa can either be taken as evidence of repeated incursions of taxa that have not yet been found outside Africa or as in situ evolution. Several other taxa also have records that suggest there may have been repeated dispersal events rather than continual occupation following their first appearances. These include carnivores, hominins and the hippos, and possibly the SW Asian alcelaphines and hippotragines. Such patterns are extremely important, as concentration simply on FADs of taxa may disguise multiple movements between continents. This may be a shortcoming of both our current perception of the evidence and also the patchy nature of the fossil record.

Arguably the sparsest, yet most examined, record of an African taxon outside Africa is that of early Homo. The earliest known fossil and archaeological material outside Africa from Dmanisi in Georgia ( 1.7 Ma) perhaps indicating a first late Pliocene/ Early Pleistocene dispersal of most primitive Homo. It has also been suggested that Homo erectus may even have dispersed back into Africa from Asia, arriving back at roughly 1.4 Ma at Olduvai Gorge (Clarke, 2000), and our data does not exclude the possibility of an immigration at this date. 
As different stone tool industries have been found sequentially in SW Asia and central Asia, it would seem logical to suggest that these are the result of separate dispersals of hominins carrying different tool types from Africa as suggested by Bar Yosef and BelferCohen (2001). However, tool kits can be adapted to local needs, and therefore equating stone tool cultures with particular taxonomic or migratory groups may be too simplistic (e.g. Field et al., 2007; Turner and O'Regan, 2007b). These latter arguments are based on later dispersals of Homo sapiens, but may be worth considering in the context of the persistence of mode 1 (Oldowan) industries in Europe long after the Acheulean had appeared elsewhere.

Two carnivores, the European cheetah, Acinonyx pardinensis and the brown hyaena-like Pliocrocuta perrieri disappeared from Europe in the earliest Pleistocene only to reappear in the earlier stages of the Middle Pleistocene at sites such as Petralona, Mauer, Mosbach 2 and, in the case of the hyaena, at the southern French sites of L'Escale and Lunel Viel (Turner, 1995). These second, restricted dispersals did not reach Britain, but the hyaena may have reached the Iberian Peninsula, in view of the presence there of what has been identified as Hyaena prisca at the Portuguese Late Pleistocene locality of Furninha (Cardoso, 1992) but which is more plausibly P. perrieri (Turner et al., 2008). Contrary to earlier suggestions (Turner et al., 2008) it also seems to have returned to Italy where it is found at Ponte Galeria in deposits dated to $0.65-0.55 \mathrm{Ma}$ (Milli and Palombo, 2005). The origins of this second dispersal into Europe may have lain in Asia, where certainly the cheetah, and perhaps also the hyaena, may have retained a presence. In the case of $P$. perrieri the return to Europe could even represent expansion from a relict population in Iberia, but we should perhaps also consider the possibility of a Middle Pleistocene dispersal from Africa in view of the similarities between P. perrieri and the brown hyaena discussed above in Section 2 .

Dispersals by Hippopotamus are also of interest. The earliest find of Hippopotamus in Europe is in the Early Pleistocene at Venta Micena in Spain (Martínez-Navarro, 2004), and 
the genus is also found at 'Ubeidiya in the Levant. However, two different species are present at 'Ubeidiya, H. gorgops, an African species, and H. behemoth, an apparent Levantine endemic (Martínez-Navarro, 2004; Belmaker 2006). Hippopotamus cf. H. behemoth has also been recorded from Latamne in Syria, dated between 0.7-0.6 Ma (Guérin et al., 1993), although Tchernov et al. (1994) believed it was earlier. The early Middle Pleistocene site of Gesher Benot Ya'aqov has Hippopotamus ?amphibius (Geraads \& Tchernov 1983; Bar-Yosef, 1998; Tchernov et al., 1994), the extant African species. Hippopotamus georgicus (=H. amphibius antiquus) has been found in Central Asia, at the late Early Pleistocene site of Akhalkalaki in Georgia (Hemmer et al., 2001), but not so far in southern and Eastern Asia, where it is possible that its niche was filled by Hexaprotodon. According to Tong (2007) Hippopotamus is not found in China, but it is conceivable that some Hippopotamus sp. identifications in India are correct. An obvious question to ask is whether hippos dispersed repeatedly from Africa or survived in refugia between their various appearances in Europe, but further work is required to resolve this issue.

\section{Summary and conclusion}

Overall we conclude that there is now little evidence for major waves of dispersal between the Pliocene and Pleistocene mammal faunas of Africa and Eurasia. Instead the pattern seems to be highly complex, with few species moving in concert. Previously identified faunal 'events' such as the Elephant-Equus event and the dispersal of African bovids into Asia at $2.5 \mathrm{Ma}$ have also been discounted, and it may be that talking in terms of events is too simplistic. It makes for a useful shorthand but can end up trapping things in its own logic, so that the appearance of a true Canis in Europe would have to be later than $1.7 \mathrm{Ma}$ on the basis of earlier ideas about a 'wolf event'. We therefore need to be clear about what we can say. Can we identify a first record, and therefore perhaps a first appearance by a taxon in a region? 
Yes. But identification of an event needs caution unless it is something like a volcanic eruption with a spread of geochemically identifiable debris, and it is worth reiterating that a First Appearance Datum is just that.

Faunal events are difficult to identify because mammals are unpredictable. We suspect that species moved alone and that Homo is not special; although repeated dispersal may be seen in the hominin record, it appears that other taxa such as Panthera may have followed a similar pattern. It is not impossible that $H$. erectus could have moved back into Africa as suggested by Clarke (2000), since it is only after 1.3 Ma that Eurasian mammals, with the possible exception of two caprines and Bos, seem to stop appearing in the African record. In terms of dispersal out of Africa, the majority of movements happened prior to $3 \mathrm{Ma}$ or between 1.8 Ma and 1.3 Ma.

Should we expect to see other African elements in a site with hominins? No, not necessarily, if we are correct in concluding that taxa did not move together. Therefore the presence or lack of African taxa within a site cannot be used uncritically either to support or to dismiss early putative archaeological assemblages. We might also ask how long does an animal have to be out of Africa to still be considered 'African' - is the hippopotamus found in British last interglacial sites, and absent since the Cromerian, still African? Surely not; it is more likely to have re-appeared from some refugium closer to hand.

We conclude that a relatively small number of Eurasian Pleistocene taxa come from Africa and those that do have differing environmental tolerances, which alone carries the clear implication that they would not have moved together. Few taxa can be shown to have gone into Africa, and there is instead much more movement between Asia and Europe than between Africa and Europe. In other words, the predominant pattern of dispersal in the AfroEurasian Pliocene and Pleistocene was east-west rather than north-south. In particular, a 
closer examination of the evidence for the Bovidae shows that neither dating nor palaeoenvironmental data suggest that they dispersed together in a wave from Africa.

The absence of any dispersal in concert calls into question the likelihood that Homo moved with other taxa, so that models of simultaneous expansion by hominins and other taxa such as that proposed by Martínez-Navarro et al. (2007) seem unlikely. Indeed the latest work on the fauna from Dmanisi states clearly that is has little overall similarity with African sites, and that it is most similar to that of Early Pleistocene Europe (Lordkipanidze et al., 2007). On face value, the known pattern of hominin fossil and archaeological evidence suggests an initial expansion through the Levant into central and eastern Asia, with expansion into Europe only in the later Early Pleistocene as evidenced by the material from sites such as Barranco Leon and Atapuerca. This would represent movement by a primitive member of Homo with Oldowan technology in the earliest Pleistocene at least as far eastwards as the Pabbi Hills and then later westwards into southern Europe. However, we stress that nothing said above should be taken to imply that because we see no evidence for hominin dispersal(s) occurring in concert with other species we consider hominins as having been entirely free to disperse at will in a manner unconstrained by things like climate or environments in the past. While technological developments and evolution of intelligence and physical capabilities over the past several million years obviously played a part in determining the ability of populations to cope in various situations, we see no reason to assume that they rendered early members of the genus Homo immune to natural factors.

\section{Acknowledgements}

We thank Adrian Lister, Guang-Biao Wei and Haowen Tong for providing reprints. Much of this work was undertaken in the context of a NERC grant under the EFCHED project, grant number NER/T/S/2002/00431. 


\section{References}

Agustí, J., Moyà-Solà, S., 1992. Mammalian dispersal events in the Spanish Pleistocene. Courier Forschungsinstitut Senckenburg 153, 69-77.

Alemseged, Z., Geraads, D., 2000. A new Middle Pleistocene fauna from the BusidimaTelalak region of the Afar, Ethiopia. Earth and Planetary Sciences 331, 549-556.

Ascenzi, A., Mallegni, F., Manzi, G., Segre, A.G., Segre Naldini, E., 2000. A re-appraisal of Ceprano calvaria affinities with Homo erectus, after the new reconstruction. Journal of Human Evolution 39, 443-450.

Arzarello, M., Marcolini, F., Pavia, G., Pavia, M., Petronio, C., Petrucci, M., Rook, L., Sardella, R., 2007. Evidence of earliest human occurrence in Europe: the site of Pirro Nord (Southern Italy). Naturwissenschaften 94, 107-112.

Asfaw, B., Beyene, Y., Suwa, G., Walter, R.C., White, T.D., WoldeGabriel, G., Yemane, T., 1992. The earliest Acheulean from Konso-Gardula. Nature 360, 732-735.

Asfaw, B., Gilbert, W.H., Beyene, Y., Hart, W.K., Renne, P.R., WoldeGabriel, G., Vrba, E. S., White, T.D., 2002. Remains of Homo erectus from Bouri, Middle Awash, Ethiopia. Nature 416, 317-320.

Azzaroli, A., De Guili, C., Ficcarelli, G., Torre, D., 1988. Late Pliocene to Early MidPleistocene mammals in Eurasia: Faunal Succession and dispersion events. Palaeogeography, Palaeoclimatology, Palaeoecology 66, 77-100.

Bar-Yosef, O., 1998. Early colonizations and cultural continuities in the lower Palaeolithic of western Asia. In: Petraglia, M.D., Korisettar, R. (Eds.), Early Human Behaviour in Global Context - The Rise and Diversity of the Lower Palaeolithic Record. Routledge, London, pp. 221-279. 
Bar-Yosef, O., Belfer-Cohen, A., 2001. From Africa to Eurasia - early dispersals. Quaternary International 75, 19-28.

Barry, J.C., 1987. Larger carnivores (Canidae, Hyaenidae, Felidae) from Laetoli. In: Leakey, M.D., Harris, J.M. (Eds.), Laetoli: A Pliocene site in Tanzania. Clarendon Press, Oxford, pp. 235-258.

Basu, P.K., 2004. Siwalik mammals of the Jammu Sub-Himalaya, India: an appraisal of their diversity and habitats. Quaternary International 117, 105-118.

Belmaker, M., 2006. Community structure through time: 'Ubeidiya, a Lower Pleistocene site as a case study. Hebrew University, Unpublished $\mathrm{PhD}$ thesis.

Belmaker, M., Tchernov, E., Condemi, S., Bar-Yosef, O., 2002. New evidence for hominid presence in the Lower Pleistocene of the Southern Levant. Journal of Human Evolution $43,43-56$.

Bettis, E.A., Milius, A.K., Carpenter, S.J., Larick, R., Zaim, Y., Rizal, Y., Ciochon, R., Tassier-Surine, S.A., Murray, D., Suminto., Bronto, S., 2009. Way out of Africa: Early Pleistocene paleoenvironments inhabited by Homo erectus in Sangiran, Java. Journal of Human Evolution 56, 11-24.

Bishop, L.C., King, T., Hill, A., Wood, B., 2006. Palaeoecology of Kolpochoerus heseloni (= K. limnetes): a multiproxy approach. Transactions of the Royal Society of South Africa $61,81-88$.

Bobe, R., Behrensmeyer, A.K., 2004. The expansion of grassland ecosystems in Africa in relation to mammalian evolution and the origin of the genus Homo. Palaeogeography, Palaeoclimatology, Palaeoecology 207, 399-420.

Bobe, R., Eck, G.G., 2001. Responses of African bovids to Pliocene climatic change. Paleobiology 27 Supplement, 1-47. 
Carbonell, E., Bermúdez de Castro, J.M., Parés, J.M., Pérez-González, A., Cuenca-Bescós, G., Ollé, A., Mosquera, M., Huguet, R., van der Made, J., Rosas, A., Sala, R., Vallverdú, J., García, N., Granger, D.E., Martinón-Torres, M., Rodríguez, X.P., Stock, G.M., Vergès, J.M., Allué, E., Burjachs, F., Cáceres, I., Canals, A., Benito, A., Díez, C., Lozano, M., Mateos, A., Navazo, M., Rodríguez, J., Rosell, J., Arsuaga, J.L., 2008. The first hominin of Europe. Nature 452, 465-469.

Cardoso J.L., 1992. Contribuição Para o Conhecimento dos Grandes Mamiferos do Pleistocénico Superio de Portugal. Universidade Nova de Lisboa, Portugal, Unpublished PhD Dissertation.

Chauhan, P.R., 2008. Large mammal fossil occurrences and associated archaeological evidence in Pleistocene contexts of peninsular India and Sri Lanka. Quaternary International 192, 20-42.

Christiansen, P., 2008. Phylogeny of the great cats (Felidae: Pantherinae), and the influence of fossil taxa and missing characters. Cladistics 24, 977-992.

Clarke, R.J., 2000. Out of Africa and back again. International Journal of Anthropology 15, 185-189.

Cooke, H.B.S., 2007. Straigraphic variation in Suidae from the Shungura Formation and some coeval deposits. In: Bobe, R., Alemseged, Z., Behrensmeyer, A.K. (Eds.), Hominin environments in the East African Pliocene, an assessment of the faunal evidence. Springer, New York, pp. 107-127.

De Lumley, H., Nioradzé, M., Barsky, D., Cauche, D., Celiberti, V., Nioradzé, G., Notter, O., Zvania, D., Lordkipanidze, D., 2005. Les industries lithiques préoldowayennes du début de Pléistocène inférieur du site de Dmanisi en Géorgie. L'anthropologie 109, 1-182. 
De Lumley, M.-A., Gabounia, L., Vekua, A.K., Lordkipanidze, D., 2006. Les restes humains du Pliocène final et du début du Pléistocène inférieur de Dmanisi, Géorgie (1991-2000). I - Les crânes, D 2280, D 2282, D 2700. L'anthropologie 110, 1-110.

Deng, C., Zhu, R., Zhang, R., Ao, H., Pan, Y., 2008. Timing of the Nihewan formation and faunas. Quaternary Research 69: 77-90.

Dennell, R., 2003. Dispersal and colonisation, long and short chronologies: how continuous is the Early Pleistocene record for hominids outside East Africa? Journal of Human Evolution 45, 421-440.

Dennell, R. (Ed), 2004 Early Hominin Landscapes in northern Pakistan: Investigations in the Pabbi Hills. British Archaeological Reports, International Series 1265, Oxford.

Dennell, R., 2009. The Palaeolithic Settlement of Asia. Cambridge University Press, Cambridge.

Dennell, R., Coard, R., Turner, A., 2006 The biostratigraphy and magnetic polarity zonation of the Pabbi Hills, northern Pakistan: an Upper Siwalik (Pinjor Stage) Plio-Pleistocene fluvial sequence. Palaeogeography, Palaeoclimatology, Palaeoecology 234, 168-185.

Dennell, R., Coard, R. \& Turner, A., 2008. Predators and scavengers in Early Pleistocene southern Asia. Quaternary International 192, 78-88.

Dennell, R., Roebroeks, W., 2005. An Asian perspective on early human dispersal from Africa. Nature 438, 1099-1104.

Estes, R.D., 1991. The behaviour guide to African mammals. University of California Press, Berkeley.

Falguères, C., Bahain, J.-J., Yokoyama, Y., Arsuaga, J.L., Bermudez de Castro, J.M., Carbonell, E., Bischoff, J.L., Dolo, J.-M., 1999. Earliest humans in Europe: the age of TD6 Gran Dolina, Atapuerca, Spain. Journal of Human Evolution 37, 343-352. 
Ferretti, M.P., Ficarrelli, G., Libsekal, Y., Tecle, T.M., Rook, L., 2003. Fossil elephants from Buia (Northern Afar Depression, Eritrea) with remarks on the systematic of Elephas recki (Proboscidea, Elephantidae). Journal of Vertebrate Paleontology 23, 244-257.

Ficcarelli, G., Torre, D., Turner, A., 1984. First evidence for a species of raccoon dog, Nyctereutes Temminck, 1938, in South African Plio-Pleistocene deposits. Bollettino della Societa Paleontologica Italiana 23, 125-130.

Field, J.S., Petraglia, M.D., Lahr, M.M., 2007. The southern dispersal hypothesis and the South Asian archaeological record: Examination of dispersal routes through GIS analysis. Journal of Anthropological Archaeology 26, 88-108.

Gabunia, L., 1974. A propos du Villafranchian du Caucase. Memoires du Bureau de Recherches Geologiques et Minieres 78, 145-148.

Gabunia, L., de Lumley, M.A., Vekua, A., Lordkipanidze, D., de Lumley, H., 2002. Découverte d'un nouvel hominidé a Dmanissi (Transcaucasie, Géorgie). Comptes Rendus Palevol 1, 242-253.

Garcia, N., Arsuaga, J.L., 2001, Les carnivores (Mammalia) des sites du Pléistocène ancien et moyen d'Atapuerca (Espagne). L'Anthropologie 105, 83-93.

Gaudzinski, S., 2004. Subsistence patterns of early Pleistocene hominids in the Levant taphonomic evidence from the 'Ubeidiya Formation, Israel. Journal of Archaeological Science 31, 65-75.

Geraads, D., 1997. Carnivores du Pliocene terminal de Ahl al Oughlam (Casablanca, Maroc). Geobios 30 127-164.

Geraads, D., Tchernov, E., 1983. Fémurs humains du Pléistocènce moyen de Gesher Benot Ya'acov. L'Anthropologie 87, 138-141. 
Geraads, D., Alemseged, Z., Reed, D., Wynn, J., Roman, D.C., 2004. The Pleistocene fauna (other than Primates) from Asbole, lower Awash Valley, Ethiopia, and its environmental and biochronological implications. Géobios 37, 697-718.

Geraads, D., Guérin, C., Faure, M., 1986. Les suidés du Pleistocene ancien d'Oubeidiyeh (Israel). Mémoires et Travaux du Centre de Recherches français de Jérusalem 5, 93-105.

Gibert, J., Gibert, Ll., Iglesias, A., Maestro, E., 1998. Two ‘Oldowan’ assemblages in the Plio-Pleistocene deposits of the Orce region, southeast Spain. Antiquity 72, 17-25.

Goren-Inbar, N., Lister, A., Werker, E., Chech, W., 1994. A butchered elephant skull and associated artefacts from the Acheulian site of Gesher Benot ya'aqov, Israel. Paléorient 20, 99-112.

Goren-Inbar, N., Feibel, C.S., Verosub, K.L., Melamed, Y., Kislev, M.E., Tchernov, E., Saragusti, I., 2000. Pleistocene milestones on the Out-of-Africa corridor at Gesher Benot Ya'aqov, Israel. Science 289, 944-947.

Guérin, C., Eisenmann, V., Faure, M., 1993. Les grands mammifères du gisement Pléistocène moyen de Latamné (Vallée de l'Oronte, Syrie). In: Sanlaville, P., Besançon, J., Copeland, L., Muhesen, S. (Eds.), Le Paléolithique de la vallée moyenne de l'Oronte (Syrie). British Archaeological Reports, International Series 587, Oxford, 169-178.

Haas, G., 1970. Metridiochoerus evronensis n. sp., a new middle Pleistocene phacochoerid from Israel. Israel Journal of Zoology 19, 179-181.

Hemmer, H., Kahlke, R-D., Vekua, A.K., 2001. The jaguar - Panthera onca gombaszoegensis (Kretzoi, 1938) (Carnivora: Felidae) in the Late Lower Pleistocene of Akhalkalaki (South Georgia; Transcaucasia) and its evolutionary and ecological significance. Geobios 34, 475-486.

Hooijer, D.A., 1958. An early Pleistocene mammalian fauna from Bethlehem. Bulletin of the British Museum (Natural History): Geology 3, 267-292. 
Hughes, J.K., Alan Haywood. A., Mithen, S.J., Sellwood, B.W., Valdes, P.J., 2007.

Investigating early hominin dispersal patterns: developing a framework for climate data integration. Journal of Human Evolution 53, 465-474.

Hughes, J.K., Elton, S., O’Regan, H.J., 2008. Theropithecus and 'Out of Africa' dispersal in the Plio-Pleistocene. Journal of Human Evolution 54, 43-77.

Kahlke, R-D., (Ed) 1997-2001. Das Pleistozän von Untermassfeld in Thüringen, Vols 1-3. Bonn, Rudolf Harbelt Verlag.

Kalb, J.E., 1995. Fossil elephantoids, Awash paleolake basins, and the Afar triple junction, Palaeogeography, Palaeoclimatology, Palaeoecology 114, 357-368.

Klein, R.G., 1999. The human career, human biological and cultural origins, Second edition. University of Chicago Press, Chicago.

Lacombat, F., Abbazzi, L., Ferretti, M., Martínez-Navarro, B., Moullé, P.-E., Palombo, M.-R., Rook, L., Turner, A., Valli, M.-F., 2008. New data on the Early Villafranchian fauna from Vialette (Haute-Loire, France) based on the collection of the Crozatier Museum (Le Puy-en-Velay, Haute-Loire, France). Quaternary International 179, 64-71.

Lewis, M., Pacher, M., Turner, A., in press. The larger Carnivora of the West Runton Freshwater Bed. Quaternary International.

Lindsay, E.H., Opdyke, N.D., Johnson, N.M., 1980. Pliocene dispersal of the horse, Equus, and late Cenozoic mammalian dispersal events. Nature 287, 135-138.

Lister, A.M., Sher, A.V., van Essen, H., Wei, G., 2005. The pattern and process of mammoth evolution in Eurasia. Quaternary International 126-128, 49-64.

Lordkipanidze, D., Jashashvili, T., Vekua, A., Ponce de Leon, M.S., Zollikofer, C.P.E., Rightmire, G.P., Pontzer, H., Ferring, R., Oms, O., Tappen, M., Bukhsianidze1, M., Agusti, J., Kahlke, R., Kiladze1, G., Martínez-Navarro, B., Mouskhelishvili, A., 
Nioradze, M., Rook, L., 2007. Postcranial evidence from early Homo from Dmanisi. Nature 449, 305-310.

Martínez-Navarro, B.M., 1992. Revisión sistemática de la fauna de macromamíferos del yacimiento de Venta Micena (Orce, Granada, Espana). In: Gibert, J. (Ed.), Proyecto Orce-Cueva Victoria (1988-1992): Presencia humana en el Pleistoceno inferior de Granada y Murcia. Ayuntamiento de Orce, Granada, pp. 21-85.

Martínez-Navarro, B.M., 2004. Hippos, pigs, bovids, sabre-toothed tigers, monkeys, and hominids: Dispersals through the Levantine Corridor during Late Pliocene and Early Pleistocene times. In: Goren-Inbar, N., Speth, J.D. (Eds.), Human Palaeoecology in the Levantine corridor. Oxbow Books, Oxford, pp. 37-51.

Martínez-Navarro, B., Palmqvist, P., 1995. Presence of the African Machairodont Megantereon whitei (Broom, 1937) (Felidae, Carnivora, Mammalia) in the Lower Pleistocene Site of Venta Micena (Orce, Granada, Spain), with some Considerations on the Origin, Evolution and Dispersal of the Genus. Journal of Archaeological Science 22, $569-582$

Martínez-Navarro, B., Rook, L., 2003. Gradual evolution in the African hunting dog lineage systematic implications. Comptes Rendus de l'Academie des Sciences Palevol 2, 695 702.

Martínez-Navarro, B.M., Turq, A., Agusti Ballester, J., Oms, O., 1997. Fuente Nueva-3 (Orce, Granada, Spain) and the first human occupation of Europe. Journal of Human Evolution $33,611-620$.

Martínez-Navarro, B., Palombo, M.R., 2004. Occurrence of the Indian genus Hemibos (Bovini, Bovidae, Mammalia) at the Early-Middle Pleistocene transition in Italy. Quaternary International 61, 314-317. 
Martínez-Navarro, B., Pérez-Claros, J.A., Palombo, M.R., Rook, L., Palmqvist, P., 2007. The Olduvai buffalo Pelorovis and the origin of Bos. Quaternary Research 68, 220-226.

Martinón-Torres, M., Bermúdez de Castro, J.M., Gómez-Robles, A., Arsuaga, J.L., Carbonell, E., Lordkipanidze, D., Manzi, G., Margvelashvili, A., 2007. Dental evidence on the hominin dispersals during the Pleistocene. Proceedings of the National Academy of Sciences 104, 13279-13282.

Milli, S., Palombo, M.R., 2005. The high-resolution sequence stratigraphy and the mammal fossil record: a test in the Middle-Upper Pleistocene deposits of the Roman Basin (Latium, Italy). Quaternary International 126-128, 251-270.

Mitchell, G., Skinner, J.D., 2003. On the origin, evolution and phylogeny of giraffes Giraffa camelopardalis. Transactions of the Royal Society of South Africa 58, 51-73.

Morwood, M.J., O’Sullivan, P.B., Aziz, F., Raza, A., 1998. Fission-track ages of stone tools and fossils on the east Indonesian island of Flores. Nature 392, 173-176.

Nanda, A.C., 2002. Upper Siwalik mammalian faunas of India and associated events. Journal of Asian Earth Science 21, 47-58.

Nanda, A.C., 2008. Comments on the Pinjor mammalian fauna of the Siwalik group in relation to the post-Siwalik faunas of peninsular India and Indo-Gangetic plain. Quaternary International. 192, 6-13.

Oms, O., Parés, J.M., Martínez-Navarro, B., Agusti, J., Toro, I., Martinez-Fernández, G., Turq, A., 2000. Early human occupation of Western Europe: paleomagnetic dates for two paleolithic sites in Spain. Proceedings of the National Academy of Sciences 97, 10666-10670.

O’Regan, H.J., 2008. The Iberian peninsula - corridor or cul-de-sac? Mammalian faunal change and possible routes of dispersal in the last 2 million years. Quaternary Science Reviews 27, 2136-2144. 
O’Regan, H.J., Turner, A., 2004. Biostratigraphical and palaeoecological implications of new fossil felid material from the Plio-Pleistocene site of Tegelen, The Netherlands. Palaeontology 47, 1181-1193.

O’Regan, H.J., Bishop, L.C., Lamb, A., Elton, S., Turner, A., 2005. Large mammal turnover in Africa and the Levant between 1.0 and 0.5Ma. In: Head, M.J., Gibbard, P.L. (Eds.), Early-Middle Pleistocene Transitions: The Land-Ocean Evidence. Geological Society Special Publications, vol 247, pp. 231-249.

O’Regan, H.J., Bishop, L.C., Elton, S., Lamb, A., Turner, A., 2006. Afro-Eurasian mammalian dispersal routes of the late Pliocene and early Pleistocene and their bearings on earliest hominin movements. Courier Forschungsinstitut Senckenberg 256: 305-314.

Palmqvist, P., Torregrosa, V., Pérez-Claros, J.A., Martínez-Navarro, B., Turner, A., 2007. A re-evaluation of the diversity of Megantereon (Mammalia, Carnivora, Machairodontinae) and the problem of species identification in extinct carnivores. Journal of Vertebrate Paleontology 27, 160-175.

Parfitt, S.A., Barendregt, R.W., Breda, M., Candy, I., Collins, M.J. Coope, G.R., Durbridge, P., Field, M.H., Lee, J.R., Lister, A.M., Mutch, R., Penkman, K.E.H., Preece, R.C., Rose, J., Stringer, C.B., Symmons, R., Whittaker, J.E., Wymer, J.J., Stuart, A.J., 2005. The earliest record of human activity in northern Europe. Nature 438, 108-1012.

Radulesco, C., Samson, P., 1990. The Plio-Pleistocene mammalian succession of the Oltet Valley, Dacic Basin, Romania. Quartärpaläontologie 8, 225-232.

Radulesco, C., Samson, P., 2001. Biochronology and evolution of the Early Pliocene to the Early Pleistocene mammalian faunas of Romania. Bolletino della Societé Paleontologica Italiana 40, 285-291.

Rieger, I., 1981. Hyaena hyaena. Mammalian Species 150, 1-5. 
Rightmire, G.P., Lordkipanidze, D., Vekua, A., 2006. Anatomical descriptions, comparative studies and evolutionary significance of the hominin skulls from Dmanisi, Republic of Georgia. Journal of Human Evolution 50, 115-141.

Roebroeks, W., 2001. Hominid behaviour and the earliest occupation of Europe: an exploration. Journal of Human Evolution 41, 437-461.

Ron, H., Porat, N., Ronen, A., Tchernov, E., Horwitz, LK., 2003. Magnetostratigraphy of the Evron Member - implications for the age of the Middle Acheulian site of Evron Quarry. Journal of Human Evolution 44, 633-639.

Sahnouni, M., de Heinzelin, J., 1998. The site of Ain Hanech revisited: new investigations at this Lower Pleistocene site in Northern Algeria. Journal of Archaeological Science 25, 1083-1101.

Sardella, R., Palombo, M.R., 2007. The Pliocene-Pleistocene boundary: which significance for the so-called “wolf event”? Evidences from western Europe. Quaternaire 18, 65-71.

Semaw, S., Simpson, S.W., Quade, J., Renne, P.R., Butler, R.F., McIntosh, W.C., Levin, N., Dominguez-Rodrigo, M., Rogers, M., 2005. Early Pliocene hominids from Gona, Ethiopia. Nature 433, 301-305.

Sotnikova, M.V., Dodonov, A.E., Pen'kov, A.V., 1997. Upper Cenozoic bio-magnetic stratigraphy of Central Asian mammalian localities. Palaeogeography, Palaeoclimatology, Palaeoecology 133, 243-258.

Spassov, N., 1998. A new Late Villafranchian locality of vertebrate fauna - Slivnitsa (Bulgaria) and the carnivore dispersal events in Europe on the Pliocene/Pleistocene boundary. Historia Naturalis Bulgarica 9, 101-113.

Swisher, C.C., Curtis, G.H., Jacob, T., Getty, A.G., Suprijo, A., Widiasmoro, 1994. Age of the earliest known hominids in Java, Indonesia. Science 263, 1118-1121. 
Tassy, P., 2003. Elephantoidea from Lothagam. In: Leakey, M.G., Harris, J.M. (Eds.), Lothagam: The Dawn of Humanity in Eastern Africa. Columbia University Press, New York, pp. 331-358.

Tchernov, E., 1992. Eurasian-African biotic exchanges through the Levantine corridor during the Neogene and Quaternary. In: von Koenigswald, W., Werdelin, L. (Eds.), Mammalian Migration and Dispersal Events in the European Quaternary. Courier Forschungsinstitut Senckenberg 153, 103-123.

Tchernov, E., Shoshani, J., 1996. Proboscidean remains in southern Levant. In: Shoshani, J., Tassy, P. (Eds.), The Proboscidea. Oxford University Press, Oxford, pp. 225-233. Tchernov, E., Horwitz, L.K., Ronen, A., Lister, A., 1994. The faunal remains from Evron Quarry in relation to other lower Paleolithic hominid sites in the southern Levant. Quaternary Research 42, 328-339.

Thomas, H., Gerrards, D., Janjou, D., Vaslet, D., Memesh, A., Billiou, D., Bocherens, H., Dobigny, G., Eisenmann, V., Gayet, M., de Lapparent de Broin, F., Petter, G., Halawani, M., 1998. First Pleistocene faunas from the Arabian peninsula: An Nafud desert, Saudi Arabia. Comptes rendus del'Academie des Sciences Paris 326, 145-152.

Tong, H., 2006. Mammalian faunal differentiations between North and South China during the Quaternary Period. L'anthropologie 110, 870-887.

Tong, H., 2007. Occurrences of warm-adapted mammals in north China over the Quaternary period and their paleo-environmental significance. Science in China Series D: Earth Sciences 50, 1327-1340.

Turner, A., 1990. The evolution of the guild of larger terrestrial carnivores in the PlioPleistocene of Africa. Geobios 23, 349-368. 
Turner, A., 1992. Large carnivores and earliest European hominids: changing determinants of resource availability during the Lower and Middle Pleistocene. Journal of Human Evolution 22, 109-126.

Turner, A., 1995. The Villafranchian large carnivore guild: geographic distribution and structural evolution. Il Quaternario 8, 349-356.

Turner, A., 1999. Assessing earliest human settlement of Eurasia: Late Pliocene dispersions from Africa. Antiquity 73, 563-570.

Turner, A., 2004. Vertebrate fossils: Carnivora. In: Dennell, R. (Ed.), Early Hominin Landscapes in northern Pakistan: Investigations in the Pabbi Hills. British Archaeological Reports, International Series 1265, pp. 404-411.

Turner, A., 2009. The evolution of the guild of large Carnivora of the British Isles during the Middle and Late Pleistocene. Journal of Quaternary Science 24. DOI: 10.1002/jqs.1278.

Turner, A., Antón, M., 1996. The giant hyaena, Pachycrocuta brevirostris (Mammalian, Carnivora, Hyaenidae). Geobios 29, 455-468.

Turner, A., Antón, M., Werdelin, L., 2008. Taxonomy and evolutionary patterns in the fossil Hyaenidae of Europe. Geobios 41, 677-687.

Turner, A., O’Regan, H.J., 2007a. Zoogeography - primate and early hominin distribution and migration patterns. In: Henke, W., Tattersall, I. (Eds.), Handbook of Palaeoanthropology Vol 1: Principles, Methods and Approaches. Springer, New York, pp. 271-290.

Turner, A., O’Regan, H.J., 2007b. Afro-Eurasian mammalian fauna and early hominin dispersals. In: Petraglia, M.D., Allchin, B. (Eds.), The Evolution and History of Human Populations in South Asia. Springer, Dordrecht, pp. 23-39.

Turner, A., Bishop, L., Denys, C., McKee, J., 1999. A locality-based listing of African PlioPleistocene mammals. In: Bromage, T.G., Schrenk, F. (Eds.), African Biogeography, 
Climate Change and Early Hominid Evolution. Oxford University Press, New York, pp. 369-399.

Van den Bergh, G.D., de Vos, J., Sondaar, P., 2001. The late Quaternary palaeogeography of mammal evolution in the Indonesian archipelago. Palaeogeography, Palaeoclimatology, Palaeoecology 171, 385-408.

Van den Bergh, G.D., Rokus Due Awe, Morwood, M.J., Sutikna, T., Jatmiko, Wahyu Saptomo, E., 2008. The youngest Stegodon remains in Southeast Asia from the Late Pleistocene archaeological site Liang Bua, Flores, Indonesia. Quaternary International $182,16-48$.

Vekua, A., 1986. The lower Pleistocene mammalian fauna of Alkhalkalaki (southern Georgia, USSR). Palaeontologica Italica 74, 63-96.

Viseras, C., Soria, J.M., Durán, J.J., Pla, S., Garrido, G., García-García, F., Arribas, A., 2006. A large-mammal site in a meandering fluvial context (Fonelas P-1, Late Pliocene, Guadix Basin, Spain): Sedimentological keys for its paleoenvironmental reconstruction. Palaeogeography, Palaeoclimatology, Palaeoecology 242, 139-168.

Vislobokova, I., 2005. On Pliocene faunas with Proboscideans in the territory of the former Soviet Union. Quaternary International 126-128, 93-105.

von Koenigswald, G.H.R., 1960. Fossil cats from the Tegelen clay. Publicates van het Natuurhistorisch Genootschap in Limburg 12, 19-27.

Vrba, E.S., 1995a. The fossil record of African antelopes (Mammalia, Bovidae) in relation to human evolution and paleoclimate. In: Vrba, E.S., Denton, G.H., Partridge, T.C., Burckle, L.H. (Eds.), Paleoclimate and Evolution with Emphasis on Human Origins. New Haven, Yale University Press, pp. 385-424. 
Vrba, E.S., 1995b. On the connections between paleoclimate and evolution. In: Vrba, E.S., Denton, G.H., Partridge, T.C., Burckle, L.H. (Eds.), Paleoclimate and Evolution with Emphasis on Human Origins. New Haven, Yale University Press, pp. 24-45.

Vrba, E.S., Gatesy, J., 1994. New antelope fossils from Awash, Ethiopia, and phylogenetic analysis of Hippotragini (Bovidae, Mammalia). Palaeontologia Africana 31, 55-72.

Wei, G., Lister, A.M., 2005. Significance of the dating of the Majuangou site for understanding Eurasian mammoth evolution. Vertebrata PalAsiatica 43, 243-244.

Wei, G., Taruno, H., Kawamura, Y., Jin, C., 2006. Pliocene and Early Pleistocene mammoths of northern China: their revised taxonomy, biostratigraphy and evolution. Journal of Geosciences, Osaka City University 49, 59-101.

Werdelin, L., Lewis, M., 2000. Carnivora from the South Turkwel hominid site, northern Kenya. Journal of Paleontology 74, 1173-1180.

Werdelin, L., Lewis, M., 2005. Plio-Pleistocene Carnivora of eastern Africa: species richness and turnover patterns. Zoological Journal of the Linnean Society 144, 121-144.

Werdelin, L., Solounias, N. 1991. The Hyaenidae: taxonomy, systems and evolution. Fossils and Strata 30, 1-104.

Zhu, R.X., Potts, R., Xie, F., Hoffman, K.A., Deng, C.L., Shi, C.D., Pan, Y.X., Wang, H.Q., Shi, R.P., Wang, Y.C., Shi, G.H., Wu, N.Q., 2004. New evidence on the earliest human presence at high northern latitudes in northeast Asia. Nature 431, 559-562

Zhu, R.X., Pots, R., Pan, Y.X., Yao, H.T., Lü, L.Q., Zhao, X., Gao., X., Chen, L.W., Gao, F., Deng, C.L., 2008. Early Evidence of the genus Homo in East Asia. Journal of Human Evolution 55, 1075-1085. 


\begin{tabular}{|c|c|c|c|c|}
\hline Taxon & Africa & Levant & Asia & Europe \\
\hline \multicolumn{5}{|l|}{ Proboscidea } \\
\hline Elephas spp. ${ }^{1}$ & $>3.0$ & $1.0-0.8$ & $>3.0$ & - \\
\hline Elephas recki/Palaeoloxodon ${ }^{2}$ & $>3.0$ & $0.8-0.7$ & 1.36 & 0.9 \\
\hline Mammuthus spp. ${ }^{3}$ & $>3.0$ & 1.5 & $>3.0$ & $>3.0$ \\
\hline \multicolumn{5}{|l|}{ Giraffidae } \\
\hline Giraffa $^{4}$ & $>3.0$ & 2.5 & $>3.0$ & \\
\hline Giraffa camelopardalis $^{5}$ & 1.0 & $0.7-0.5$ & - & - \\
\hline \multicolumn{5}{|l|}{ Carnivora } \\
\hline Canis spp. ${ }^{6}$ & $>3.0$ & $<2.5$ & $<2.5$ & $>3.0$ \\
\hline Pachycrocuta brevirostris ${ }^{7}$ & $>3.2$ & - & 1.66 & 1.5 \\
\hline 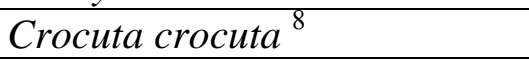 & 3.5 & 1.5 & $<2.5$ & 0.8 \\
\hline $\begin{array}{l}\text { Parahyaena brunnea/ } \\
\text { Pliocrocuta perrieri }^{9}\end{array}$ & $>3.0$ & - & - & $>3.0$ \\
\hline Panthera pardus ${ }^{10}$ & 3.5 & - & - & 0.9 \\
\hline Panthera leo ${ }^{11}$ & 3.5 & - & - & 0.7 \\
\hline Panthera sp. ${ }^{12}$ & 3.5 & 1.5 & $<2.5$ & 1.9 \\
\hline Megantereon whitei ${ }^{13}$ & $>3.0$ & 1.5 & 1.7 & 1.5 \\
\hline \multicolumn{5}{|l|}{ Primates } \\
\hline Homo spp. ${ }^{14}$ & $\sim 2.0$ & 1.5 & 1.7 & $\begin{array}{l}1.2-1.1(\mathrm{f}) \\
1.4(\mathrm{a})\end{array}$ \\
\hline Theropithecus oswaldi ssp. ${ }^{15}$ & 2.4 & $? 1.5$ & 0.6 & 1.0 \\
\hline \multicolumn{5}{|l|}{ Suidae } \\
\hline Kolpochoerus olduvaiensis ${ }^{16}$ & 1.65 & 1.5 & - & - \\
\hline Kolpochoerus evronensis ${ }^{17}$ & - & $1.0-0.8$ & - & - \\
\hline Potamochoerus sp. ${ }^{18}$ & 1.9 & - & $<2.5$ & 1.8 \\
\hline \multicolumn{5}{|l|}{ Hippopotamidae } \\
\hline Hippopotamus antiquus ${ }^{19}$ & & 2.5 & 1.0 & $\sim 1.3$ \\
\hline Hippopotamus gorgops ${ }^{20}$ & $\sim 2.0$ & 1.5 & - & - \\
\hline Hippopotamus behemoth ${ }^{21}$ & - & 1.5 & - & - \\
\hline $\begin{array}{l}\text { Hippopotamus amphibius }{ }^{22} \\
\text { (maybe synonymous with } H \text {. } \\
\text { antiquus) }\end{array}$ & $<1.33$ & $? 0.8-0.7$ & & \\
\hline \multicolumn{5}{|l|}{ Bovidae * } \\
\hline Hippotragus spp. ${ }^{23}$ & $>5.0$ & 1.5 & $>2.5$ & - \\
\hline Oryx sp. ${ }^{24}$ & $>2.5$ & $1.5-1.0 ?$ & $3.4-3.0$ & - \\
\hline Damalops sp. $^{25}$ & $\sim 3.6$ & - & $<2.5$ & - \\
\hline Alcelaphini indet. ${ }^{26}$ & $\sim 5.0$ & $1.0-0.8$ & $<2.5$ & - \\
\hline Reduncini $^{27}$ & 6.5 & - & $<2.5$ & - \\
\hline Pelorovis oldowayensis ${ }^{28}$ & $>2.5$ & 1.5 & - & - \\
\hline
\end{tabular}

Table 1. First appearances of species, genera, or tribes of African origin outside Africa between $3.0-0.5 \mathrm{Ma} .<=$ first occurrence is at this date or after, used particularly for the Siwaliks deposits where only the terminal/earliest dates of the Formations are known in 
detail. $>=$ first occurrence is before this date. $?=$ possible occurrence, see individual animals for details. * all bovid movements are discussed in detail in the text. - indicates no record of the taxon in that continent. Where a locality is only attributed to a date range, the mid-point of that range has been used.

Sources of dates. Proboscidea: 1) Tassy (2003), Tchernov et al. (1994), Ron et al. (2003), Basu (2004). 2) Ferretti et al. (2003), Goren-Inbar et al. (1994, 2000), Agusti and Moyà-Solà (1992), Deng et al. (2008). 3) Radulescu and Samson (1990, 2001), Lister et al. (2004), Wei and Lister (2005). Giraffidae: 4) Mitchell and Skinner (2003), Hooijer (1958). 5) Mitchell and Skinner (2003), Guérin et al (1993). Carnivora: 6) Hoojier (1958), Lacombat et al. (2008), Nanda (2002). 7) Werdelin and Lewis (2000), Turner and Antón (1996), Turner (2004), Deng (2008), Dennell et al. (2008). 8) We have considered all fossil taxa to be Crocuta crocuta (Turner, 1990), but see Werdelin and Lewis (2005) for an alternative view, Barry (1987), Belmaker (2006), Basu, (2004), Nanda (2002), Garcia and Arsuaga (2001). 9) Parahyaena brunnea and Pliocrocuta perrieri maybe conspecific (Turner, 1990, 1995), Turner (2009), Werdelin and Lewis (2005). 10) Barry (1987), Turner (2009). 11) Barry (1987), Turner (1990), Parfitt et al. (2005). 12) Includes both Panthera gombaszoegensis from Europe and Panthera sp. from Asia - von Koenigswald (1960), O’Regan and Turner (1994), Spassov (1998), Belmaker (2006), Nanda (2002). 13) Palmqvist et al. (2007). Primates: 14) f = fossils, Klein (1999), de Lumley et al. (2006), Zhu et al. (2008), Carbonell et al. (2008), a = archaeology, Martínez-Navarro et al. (1997), Gibert et al. (1998), Oms et al. (2000), Ascenzi et al. (2000). 15) Hughes et al. (2008). Suidae: 16) Cooke (2007), Bishop et al. (2006), Geraads et al. (1986). 17) Haas (1970), Tchernov et al. (1994), Ron et al. (2003). 18) Turner et al. (1999), Bobe and Eck (2001), Nanda (2002), Viseras et al. (2006). Hippopotamidae: 19) Hooijer (1958), Belmaker (2006), (Hemmer et al. 2001), Martínez-Navarro (1992). 20) Turner et al. (1999), Ferretti et al. (2003), Belmaker (2006). 21) Belmaker (2006). 22) Turner 
et al. (1999), Bobe and Eck (2001), Geraads and Tchernov (1983), Bar Yosef (1998).

Bovidae: 23) Gaudzinski (2004), Pilgrim (1933), Vrba (1995a), Vrba and Gatesy (1994). 24) Gabunia (1974), Vislobokova (2005), Vrba (1995a), Thomas et al. (1998). 25) Sotnikova et al. (1997), Vrba (1995a). 26) Thomas et al. (1998), Tchernov et al. (1994), Ron et al. (2003), Vrba (1995a). 27) Vrba (1995a). 28) Tchernov et al. (1994), Thomas et al. (1998), MartínezNavarro (2004). 